\title{
PROCLUS OF CONSTANTINOPLE: ENCOMIA ON THE APOSTLES PAUL AND ANDREW (HOMILIES 18 AND 19)
}

\author{
J.H. Barkhuizen \\ (University of Pretoria)
}

\begin{abstract}
The purpose of this article is to provide an annotated translation of two homilies of Proclus of Constantinople dedicated to the apostles Paul (homily 18) and Andrew (homily 19). Their treatment in one article is justified because of the fact that a section of one homily is repeated in the other (the relevant passages are added as appendix at the close of the article), and also the fact that both belong to the genre of the hagiographical homily (commemoration of the saints). The translations are accompanied by notes on various aspects of style and theology of the homilies, including a detailed reference to biblical allusions. This is followed by remarks on the content and structure of each homily. The contents of the homily on Paul is based on an overall picture of his lifeexperiences in the service of the gospel of Christ, as these are witnessed in his letters and the Acts of the Apostles, while the homily on Andrew is in part based on the words of Andrew himself in John 1.41 ("We have found the Messiah"). The homily on Paul is dominated by athletic and military images, which are part and parcel of the hagiographical genre, while the image of the fishing-net (of the Gospel) dominates the homily on Andrew.
\end{abstract}

\section{Introduction}

In presenting the reader in this article with an annotated translation in English of homilies 18 and 19 of Proclus of Constantinople, each an encomium on the apostle Paul and Andrew respectively, I thus complete a goal which I have set myself since the latter years of the previous century: the introduction to and the translation of the $\left(\mathrm{Greek}^{1}\right)$ homilies of Proclus, bishop of Constantinople (died A.D. 446). The major work was published as the first in the series Early Christian Studies (published by The Centre of Early Christian Studies, The Catholic University of Australia, Brisbane). In that publication ${ }^{2}$ the translation focussed on 27 homilies covering the theme: Homilies on the life of Christ. Subsequent articles have covered (in chronological order of publication) homily 27 on baptism, ${ }^{3}$ homily 17 on St. Stephen, ${ }^{4}$ and homily 34 on all the saints, ${ }^{5}$ the latter two forming part of the hagiographical output of Proclus, to which genre homilies 18 and 19 also belong. However, in the case of homily 18 and 19, it should be noted that both encomia relate not to the martyrdom of either of these apostles, as reported in the later apocryphal acts ${ }^{6}$ of Paul and Andrew, but merely to 
their calling and their work: the proclamation of the Gospel, and their successes and sufferings for the sake of the Gospel, as these aspects are described in the New Testament.

Finally: The reason why these two homilies are here treated together in the same article is of a practical and formal nature: the note, accompanying homily 18 in $P G$ 65.817-818, explains it sufficiently: 'Haec Procli Oratio, sequenti in Andream apostolum valde affinis est, ut etiam eadem verba ex altera in alteram ab auctore derivata sint'. The similarity in language and style of these two homilies, especially regarding the reference to the apostolic office in both homilies, calls for one overview rather than treating them separately.

\section{Annotated translation of homily $\mathbf{1 8}^{7}$}

I.

No one is weak and ill when Paul is contending. ${ }^{8}$ For together with his head-cloths, ${ }^{9}$ even recollections (of him) mow down ${ }^{10}$ illnesses.

No one then is weak and ill when Paul is contending.

The contest of the tent-maker (Acts 18.3) is a strong remedy ${ }^{11}$ against illnesses.

(5) Therefore the feast ${ }^{12}$ of Paul is radiant and bright; the spectacles of Tarsus are wonderful.

While Paul, that boxer ${ }^{13}$ of piety, is contending, everything ${ }^{14}$ is filled with joy:

Paradise, which he inhabited;

Heaven, which he seized; ${ }^{15}$

The world, which he imbued with wisdom; ${ }^{16}$

(10) The abyss, ${ }^{17}$ which he sanctified;

The sun, alongside which he ran (his course);

The basket, ${ }^{18}$ which he made distinguished;

Creation, which he conquered;

The Church, which he made very abundant; ${ }^{19}$

(15) The prison, which he illuminated; ${ }^{20}$

The tomb, which he adorned;

Everything is observing Paul's contests:

The courses of the tent-maker;

The wrestling bouts of the athlete;

(20) The marks of the boxer;

The trophies of the soldier; ${ }^{21}$

The cargo of the steersman; 
The vineyard of the farmer;

The medicine chest of the physician;

(25) The flight of the eagle;

The fall ${ }^{22}$ of the demons;

The shame ${ }^{23}$ of the devil;

The desolation of the synagogues;

The destruction of the idols, ${ }^{24}$

(30) The power of the cross (Rom. 1.16);

The bridle of the voice;

The prey ${ }^{25}$ of the lightning;

The boldness of the rage;

The benevolence of the calling;

(35) The orthodoxy of the response;

The cure of blindness;

The birth pangs of the baptismal font; ${ }^{26}$

The authority and confidence of the proclamation (of the gospel); ${ }^{27}$

Forgetfulness of the law; ${ }^{28}$

(40) The zealous care for the word. ${ }^{29}$

For Paul, the unconquerable soldier, conquered while doing battle, ${ }^{30}$ and spoke loudly ${ }^{31}$ while he was clearly and truly expressing himself everywhere.

Creation (the world?) shot its arrows (at him), but faith armed (him).

Tarsus produced (him) ${ }^{32}$ but paradise seized (him);

(45) Damascus regenerated (him) (Acts 9), but the world called (him) blessed;

Rome buried (him), ${ }^{33}$ but heaven crowned (him);

Marks were made on his body, ${ }^{34}$ but every tongue praised the contest.

Soon the rays of celebrations shone forth, and everything was filled with admiration for Paul:

(50) The epistles, nets ${ }^{35}$ of salvation;

The head-cloths, sickles of sufferings $;{ }^{36}$

The tongue, a flute of the one crucified; ${ }^{37}$

The fall, the awakening of the world;

Blindness, the true-sightedness of faith;

(55) The basket, the net ${ }^{38}$ of the gospel;

The wounds, the cures ${ }^{39}$ of the world;

The race courses, the providers of prizes;

The shipwreck (Acts 27.39-42), the rudder of the Church;

The chains, the bond of love;

(60) The blood, the libation of the love for mankind; 
The tomb, the nobility of the Romans;

Recollection (memory), ${ }^{40}$ the glory of those of the right faith.

\section{II.}

There is in life really nothing of such a nature as the apostolic grace.

The law indeed contained ${ }^{41}$ many wonderful things, but when the Sun rose, the lamp was

(65) extinguished. ${ }^{42}$

And there is in life nothing of such a nature as (the) apostles:

They ministered unto (served) the word; ${ }^{43}$

They touched the One-without-form who became flesh (1 John 1.1);

They followed him when he was walking about, he who is everywhere

(70) present;

They heard a voice of One calling things not yet in existence as if they already were

(Rom. 4.17);

They caught the world through (the net of) the tongue;

Like eagles they circumvented the ends (of the earth);

They rooted out deceit (erring) like tares;

(75) They set altars on fire like thorny thistles;

They destroyed ${ }^{44}$ idols like wild animals (beasts);

They put the demons to flight like wolves;

Like shepherds they gathered the Church together;

They gathered those of the right faith like ears of corn;

(80) They treated worthless heresies like chaff $;^{45}$

They caused Judaism to become arid like grass;

They tore Hellenism in pieces like (wooden) material; ${ }^{46}$

They ploughed the world with the cross;

They sowed the word like corn;

(85) Like morning stars they illuminated everything (Phil. 2.15).

Therefore the Lord just now ${ }^{47}$ called out to Paul:

'My grace is all you need (II Cor. 12.9).

O Paul,

like the sun you have illuminated everything with your proclamation

(of the gospel);

(90) like a moon you have driven away the darkness of ignorance;

like an eagle you have soured up towards heaven;

like a pearl you have shone in the abyss.

My grace is all you need.

Look at your victories, 
(95) and proclaim my power. ${ }^{48}$

My grace is all you need'.

Authorities were enraged;

People (crowds) were standing up against (him) ${ }^{49}$

Kings were condemning (him); ${ }^{50}$

(100) Cities were in turmoil;

Jews were lying in wait; ${ }^{51}$

Gentiles wanted to saw (him) asunder;

Swords were being sharpened;

Chains were being prepared,

(105) but Paul has stood as a rock against afflictions calling out:

Who can separate us from the love of Christ? (Rom. 8.35).

$\mathrm{O}$ head, adorned ${ }^{52}$ not with hair, but with victories!

\section{III.}

For consider with me again the contests of Paul, and you will be amazed at his crowns:

He won the Romans over through an epistle;

(110) He took the Corinthians captive ${ }^{53}$ through a cross;

He converted the Galatians through rebuke, ${ }^{54}$

He dashed to the ground Artemis of the Ephesians (Acts 19.28);

He took the Athenians captive through an altar (Acts 17.22-23);

In Philippi he gained the jailer (for Christ) (Acts 16.25-34);

(115) In (Pisidian) Antioch he made an emphatic speech in public (Acts 13.16ff.);

In Iconium he was buried under a thick shower of stones (Acts 14.19);

In Lystra he uttered a word (and thus strengthened) the feet for a lame man

(Acts 14.8-10);

In Troas he brought Eutychus back to life (Acts 20.9-10);

On the island he triumphed over a viper (Acts 28.3-5);

(120) In Cyprus he blinded the sorcerer (Acts 13.6-11);

In Jerusalem he pleaded the case of the cross (Acts 22.1ff.);

A place (of contest) followed, but his course did not slacken.

From everywhere (streams of) perils, as from fountains, were flowing towards him.

Perils from rivers (II Cor. 11.26), but they did not belittle the heap of his virtues.

(125) Perils from thieves, but they did not rob the treasure of his faith. 
Perils stemming from his race, but the earthly man stood steadfast like a heavenly man.

Perils stemming from gentiles, but they did not destroy the walls of the gospel.

Perils in cities, but they did not outwit the victor of the world.

(130) Perils in desolate places, but the theatre of the gospels saw the victory.

Perils at sea, but they did not sink the ship of perseverance.

Perils among false brothers, but from the Jews he received angels. Truly the art of temptation failed the devil, but a crown (of victory) was not wanting $^{55}$ (135) for Paul.

IV.

Therefore, let us admire all the limbs of Paul:

$\mathrm{O}$ head, citadel of virtues!

$O$ eyes, which reflected the Holy Trinity!

$\mathrm{O}$ tongue, thundering noise of theology!

(140) O marks, brighter than stars!

O hands, modellers of limbs!

O feet, goal of the gospel's course!

O words, physicians ${ }^{56}$ of souls!

$\mathrm{O}$ epistles, fishing-net ${ }^{57}$ of salvation!

(145) O breast, ocean of caring!

O drops of sweat, moistening (irrigating) the Church!

O man, pillar of faith!

$\mathrm{O}$ treasure, that has enriched the world!

O physician ${ }^{58}$ who cured the error!

(150) O corpse, that never dies!

$\mathrm{O}$ apostle, silent in the tomb, but calling from heaven:

For to me life is Christ, and death is gain! (Phil. 1.21)

To him (i.e. Christ) belongs ${ }^{59}$ the glory, and the power, together with the Father, and the Holy Spirit,

(155) now and for ever, and for ages to come. Amen.

\section{Contents and structure of homily $\mathbf{1 8}$}

The basic characteristic of homily 18 is an encomium or eulogy, ${ }^{60}$ in which the preacher presents the apostle Paul ${ }^{61}$ to his audience, by using the traditional agonistic image $^{62}$ of the hagiographical ${ }^{63}$ genre, while he selects and lists various aspects of his life and work in the form of a 
successive use of enumeration, a rhetorical technique which is so much part and parcel of the homilies of Proclus. ${ }^{64}$ The homily contains no less than ten lists referring to Paul's contests, including his opponents or objects of opposition, as well as the results of these contests. Homily 18 is therefore, among the homilies of Proclus, the most conspicuous example of the technique of enumeration or cataloguing. This, at the same time, serves to illustrate the symmetry and rhythm, which here give to the homily, as also to the other homilies of Proclus, 'a distinctive melodious sound', 'coming close to the hymnic', ${ }^{65}$ marking Proclus' style clearly as rhythmic or poetic prose. ${ }^{66}$ The ten lists are introduced and connected with each other in various ways or links, all serving to render a continuous flow of praise and eulogy:

Introduction (lines 1-6): The homily, and at the same time, the first list, is introduced with the remark that no person is ill and weak while/when Paul is involved in battle, a reference to the radiance of his feast, and that everything is therefore filled with joy.

- First list (lines 7-16): Everything is filled with joy at Paul's contests - these include: paradise, heaven, the world, the deep (abyss), the sun, the basket, creation, the Church, the prison, and the tomb.

○ Link (line 17): The second list, containing the contests/struggles of Paul, is linked with the first list by means of word repetition using the word 'everything'/'all': everything is filled with joy (first list) - everything/all observes his contests.

- Second list (lines 18-40): Twenty-three aspects, defining the contest of Paul, are listed.

○ Link (lines 41-42): A remark that Paul was victorious as unconquerable soldier, leads to the third list.

- Third list (lines 43-47): A list containing references to creation, Tarsus (where he was born), Rome (where he was buried), Damascus (where he was reborn), and to the torture marks on his body.

- Link (lines 48-49): The fourth list is introduced by the repetition of the motif of everyone being filled with joy and admiration for Paul.

- Fourth list (lines 50-62): A lists of objects filled with admiration for Paul

o Link (lines 63-66): A remark concerning the office of apostle leads to the fifth list. 
- Fifth list (lines 67-85): A list describing the admirable ministry of apostles.

○ Link (line 86): The preacher concludes the fifth list by quoting II Cor. 12.9 (My grace is all you need), which again introduces the sixth list, and which again flows over (without any break) into list seven containing some of the hardships of Paul.

- Sixth list (lines 87-96): A list serving as expansion of II Cor. 12.9 (My grace is all you need).

- Seventh list (lines 97-106): A list containing the results of God's grace that was sufficient for Paul.

○ Link (line 107): List seven is concluded by means of an exclamatio, referring to Paul's head adorned not with hair but with victories.

○ Link (line 108): The preacher introduces list eight by calling on his audience to contemplate these very victories of Paul.

- Eigth list (lines 109-121): A list of the contests of Paul with references to cities in which he worked.

○ Link [link 8a+b - lines 122-123): The preacher concludes (122) list eight and introduces (123) list nine with another reference to the perils and dangers Paul had to face.

- Ninth list (lines 124-133): A list of perils that Paul had to face.

○ Link (lines 134-135): List nine is concluded by another reference to Paul's crowns of victory.

- Link (line 136): The final list is introduced by an exhortation directed at the audience to praise the limbs of Paul, which he employed in his service of the gospel

- Tenth and final list (lines 137-152): A list (in the form of exclamatio) mostly regarding Paul's limbs in service of the gospel.

- Conclusion: The homily is concluded by the doxology (153-156)

\section{Annotated translation of homily 19}

I.

The net of the apostolic fishing is strong. ${ }^{67}$

The casting-net of commemorating Andrew is wonderful.

Unbroken is the net of the immortal dead.

For with time the snares, which not human skill, but grace has weaved, do not grow old. 
(5) For even if the fishermen were to depart from life, yet the instruments of eloquent fishermen do not grow old with time, as well as the net with/in which they catch the world.

Those who draw (the nets) are not seen, but the nets have been filled.

They have not obtained a fishing rod, which time destroys.

(10) They did not let a fishing net down, which age cuts through.

They have not forged an anchor, which rust destroys.

They have not attached bait to a snare for fishes.

They have not sat on a rock, which the waves are shaking.

They have not gone aboard a boat, which a storm destroys.

(15) They have not caught fish, the folly of nature.

But just as human skill is wonderful, in the same way also (their) instruments are wonderful and unique.

For instead of a fishing rod, they handle the proclamation of the gospel.

And instead of a fishing line, they release (the line of) commemoration.

(20) Instead of an anchor, they put forth power.

Instead of bait, they attach miracles (to the snare).

Instead of a rock, they catch from heaven.

Instead of a boat, they laid hold of the altar.

Instead of fish, they catch kings.

(25) Instead of a net, they have thrown out the gospel.

Instead of human skill, they have used grace.

Instead of a sea, they travel through life.

And instead of nets, they fish with the cross.

Who has ever seen dead people fishing, and live people being fished?

(30) $\mathrm{O}$ for the power of the One crucified!

O for the divine dignity!

$\mathrm{O}$ for the apostolic beneficence!

There is indeed nothing in life of such a nature as the apostolic grace.

II.

Life indeed saw many wonderful things, and things beyond expectation.

(35) It saw blood calling forth after it has been shed, and murder calling out without a tongue, and nature being torn on account of envy, and the earth defiled on account of a brutal act, and the murder of a brother sending one born from the same mother forth to his death,

and the door of death being opened on account of jealousy. ${ }^{68}$

It saw an ark (becoming) in shipwreck the womb of nature. ${ }^{69}$ 
(40) It saw an old man being armed against his own offspring on account of his faith.

It saw one sacrificing another who was not slaughtered, and offering one who was not killed. ${ }^{70}$

It saw a tent more spacious than heaven, and God contained under (the roof of) a tent. ${ }^{71}$

It saw a theft, the source of blessings, ${ }^{72}$ and a wrestling (match) between Maker and slave. ${ }^{73}$

It saw envy progressing among brothers, and slavery producing kingship.

(45) It saw dreams having prepared a throne, and having brought famine to the plotters. ${ }^{74}$

It saw fire bedewing a bramble-bush, ${ }^{75}$ and a staff as source of miracles. ${ }^{76}$ It saw waves being deprived, ${ }^{77}$ and depth illuminated.

It saw ways made ready, and a pillar of a cloud $\ldots{ }^{78}$ guiding the famous throng of people (Ex. 13.21-22).

(50) It saw a staff having blossomed without soil (Num.17.8), and heaven having turned manna into bread (Ex. 16.14).

It saw a lawgiver having commanded elements (of nature), and a letter (of law) bursting forth with a curse.

It saw a man having controlled the sun with a word (Jos. 10.12-13), and a sterile woman having given (55) birth to a prophet through prayer. ${ }^{79}$

It saw a handful of flower, richer than (fields) with a deep crop, and a flask of oil, more bounteous than fountains (I Kings 17.14-16).

It saw a prophet being taken up in an immaterial chariot, ${ }^{80}$ and bones of the dead (becoming) remedies of life. ${ }^{81}$

(60) These and other many wonderful things life saw, ${ }^{82}$ but those have passed by were like a shadow and grass, and like a lamp extinguished.

For when the sun rose,$^{83}$ the shadow passed by, because there is nothing of such a nature as the apostles.

\section{III.}

They served God through the word (Luke 1.2);

(65) they touched the One without form who became flesh (I John 1.1);

they followed him $^{84}$ when he walked around, yet being present everywhere; they reclined ${ }^{85}$ together with the One who is not circumscribed;

they heard a voice of One who created everything with his word; ${ }^{86}$ they caught the world through their tongue;

(70) in their course they travelled around to all ends (of the world);

they rooted out the error like tares;

they mowed down altars like thistles;

they destroyed idols like beasts; 
they put the demons ${ }^{87}$ to flight like wolves;

(75) they gathered the Church like a flock (of sheep);

they gathered those of the right faith like corn;

they treated the heresies as worthless like chaff; ${ }^{88}$

they made Judaism arid like grass;

They destroyed Hellenism with fire like wooden material;

(80) they ploughed nature with the cross;

they sowed the word like corn;

Like morning stars they illuminated everything.

Therefore the Lord called unto them:

'You are the light for the world (Matt. 5.14).

(85) You have the sunrise as virgin birth;

the dawn as the womb of baptism;

radiance, the grace of the One crucified;

rays as astounding tongues;

day as the coming age;

(90) noon as the hour of the cross;

sunset as the habitation of the tomb;

evening as temporary death;

illumination as the resurrection of the dead.

You are the light for the world (Matt. 5.14).

(95) Behold the stars, and be amazed at their radiance!'

IV.

Therefore today Andrew, having found the Lord, who is shared in common just like a treasure of light, has called to Peter, his own brother, saying:

'We have found the Messiah'(John 1.41).

$\mathrm{O}$ excess of brotherly love!

(100) O inversed order!

Though Andrew came second after Peter into life, yet he was first that caught Peter for the gospel.

'We have found the Messiah' (John 1.41), he said.

The word sprang from excessive joy.

(105) Radiant are the tidings of his founding (the Messiah).

'We have found', he says, 'the treasure.

Peter, flee from the poverty of circumcision!

Doff the rags of the law!

Throw away the yoke of the letter!

(110) Deny all these things as being of little value, and the present things that belong to the world of dreams!

(Judge) Bethsaida as a place of little worth, ${ }^{89}$ 
the casting-net as instrument of poverty, the boat as sea of shipwreck, (115) human skills as source of a storm, the fish as merchandise of gluttony, the earth as ocean of tumult, your race as vine-switches of corruption, the world as market of the belly, (120) the temple as cave of bandits (Matt. 21.13);

Jerusalem as abode of many prophets (Matt. 23.37), the nation as rage against God, Caiaphas as father of an evil Sanhedrin. We have found the Messiah (John 1.41), (125) whom the prophets proclaimed beforehand, whom the law designated beforehand.

We have found the treasure of the law. Peter, flee from the famine of the letter. We have found the Messiah (John 1.41), (130) whom the symbols foreshadowed, whom Micaiah saw on the throne of glory (I Kings 22.19), whom Isaiah saw upon the seraphim (Is. 6.6), whom Ezekiel saw upon the cherubim (Ez. 10.1), whom Daniel saw upon the clouds (Dan. 7.13), (135) whom Nebuchadnezzar saw in the furnace (Dan. 3.26ff.), whom Abraham received in his tent (Gen. 18.1ff.), whom Jacob did not let go unless being blessed (Gen. 32.22ff.), whom Moses saw (in the crevice of) the rock from behind (Ex. 33.22). Him we have found, born without beginning, and revealed in these last days.

(140) The treasure, the abundance of which is not emptied, and the richness, which cannot be robbed, and whose existence is without beginning, and the finding is recent.

We have found the Messiah, which, being translated, means: Christ. (145) There have been many 'anointed ones', but all were slaves to death. ${ }^{90}$ Abraham was an 'anointed one', but his body was dissolved in a tomb; Isaac was one, ${ }^{91}$ but the memory of him lies in bones;

Jacob was one, but he has become subordinate to death; Moses was one, but we do not even know where he is buried (Deut. 34.6); (150) David was an anointed one, but all were spoils (of death). All were 'anointed ones', but they were prisoners of death. But one was the Christ, in nature God, in his mercy man. ${ }^{92}$ 
He sealed with his birth the womb of the virgin, and rendered the fishermen to be fountains of remedies. ${ }^{93}$

(155) To him belong the power, and the kingdom and the glory, and the worship,

together with his Father, the immaculate and consubstantial one, of the same power as he, and the Holy Spirit,

now and ever, and till all ages, Amen.

\section{Contents and structure of homily 19}

The homily reveals the following structure:

- Lines 1-33, forming the first paragraph of the homily, are dominated by the fishing image, which is based on the calling of the disciples when Jesus said: 'Come with me, and I will make you fishers of men' (Matt.4.19). The preacher concludes his introduction with the remark that nothing can compares in worth with the office of the apostles.

- Lines 34-63 serve as explanation of the preacher's remark in line 33 regarding the high calling of apostleship. Life - here personified by Proclus - has seen many wondrous and paradoxical events, and he lists - again we have the well-used technique of enumeration as in homily 18 - various events from the Old Testament, but he concludes - in the form of an inclusio - that these events were mere shadows in comparison with the sun (Christ).

- Lines 64-95 revert to the apostles, and there follows a list of their activities as servants of God's word and the sub-section (64-84) concludes with Jesus' words that they are the light for the world (Matt.5.14), followed by the use of various images (in the form of comparisons, e.g. they put demons to flight as if they were wolves) employed to illustrate this apostolic activity. The fact that they are the light for the world leads to the second sub-section (85-95) in which the concept of light and elements of light are focussed upon.

- Lines 96-154 relate to Andrew's calling before that of his elder brother Peter, and his act of introducing Peter to Christ, the Messiah, whom he has found (John 1.41). The section contains a dramatized speech put in the mouth of Andrew, patterned as follows: The words: We have found the Messiah (John 1.41) form a link between the following sub-sections of Andrew's speech:

o first he exhorts Peter to doff things that belong to his old life as fisherman (96-123); 
- secondly he employs the concept of the pre-figuration and preproclamation of Christ by various Old Testament figures (124143);

O thirdly he reflects upon the fact that there were many 'anointed ones' ( $\chi \rho\llcorner\sigma \tau o$ í), like Abraham, Jacob, Isaac etc., but they have all seen death, while there is but one Christ, both God and man!

- Lines 155-158 form the concluding Trinitarian doxology.

\section{Appendix. Homily 18 and 19: a comparison.}

As stated above in the introduction, Proclus has re-employed in one homily words, phrases and concepts occurring in the other. A comparison reveals 21 concepts with one member from each, except the first concept, which has 4 members. The reader will notice that in some of these concepts there are some minor differences. All these phrases relate to the dignified office of apostle and occur in paragraph II of homily 18 and in paragraphs II-III of homily 19 . Note that (PG) 65.820 refers to homily 18 , and $65.824 / 5$ to homily 19:

1.

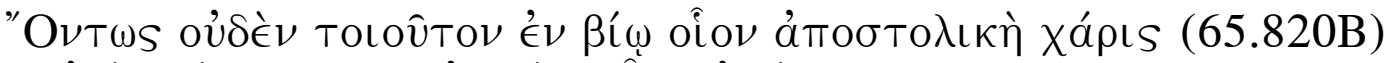

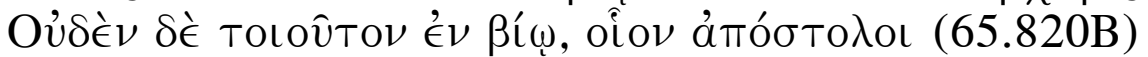

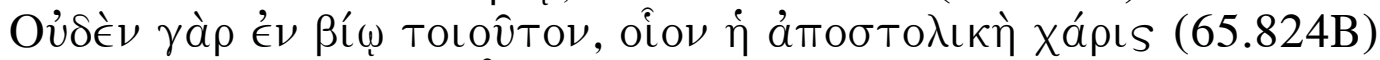

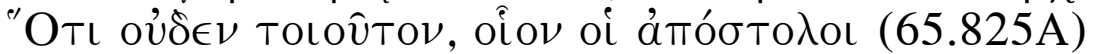

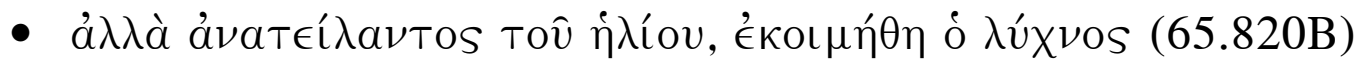

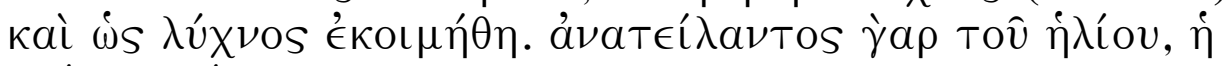

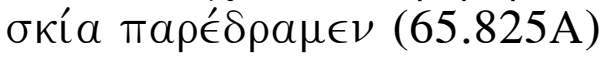

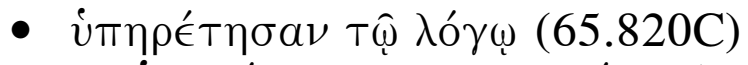

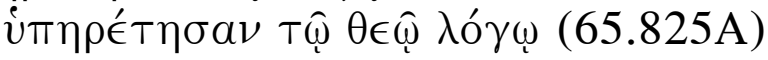

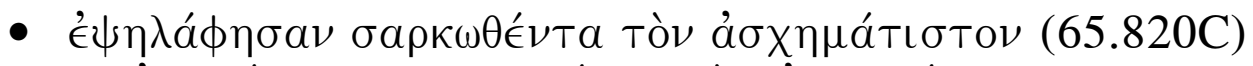

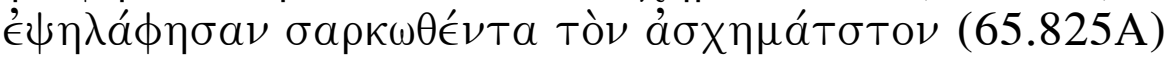

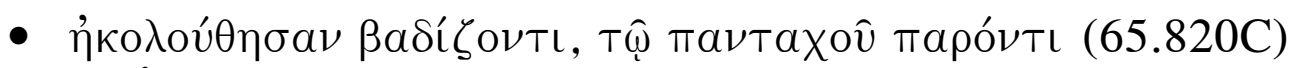

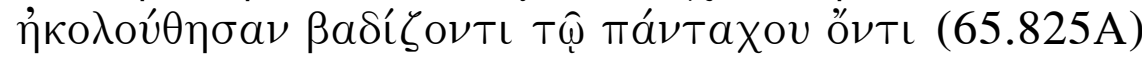

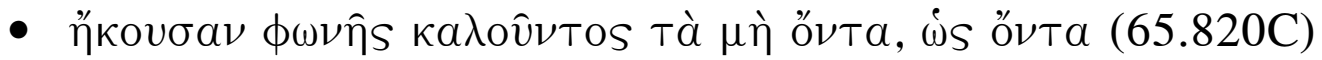

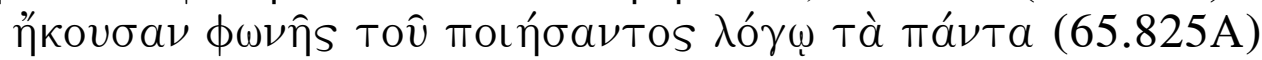




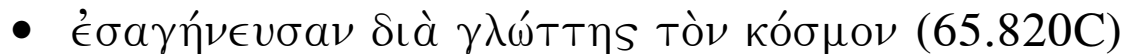

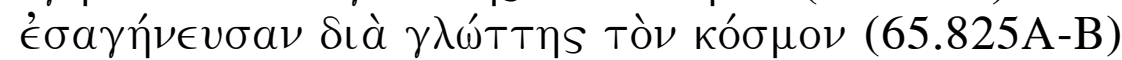

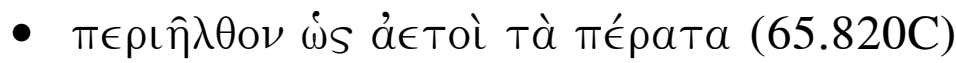

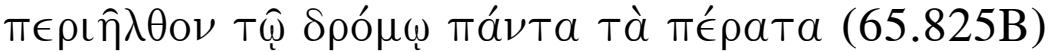

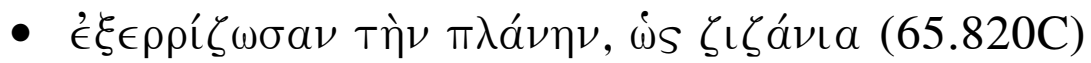

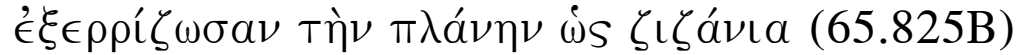

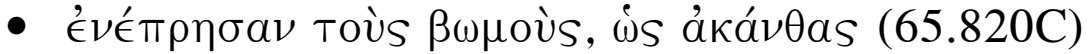

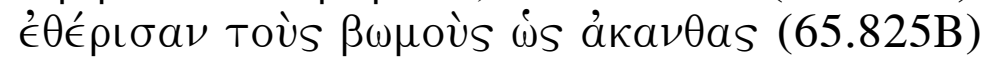

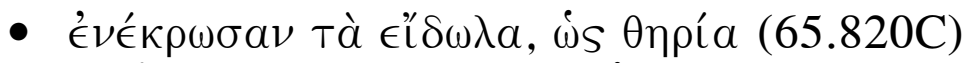

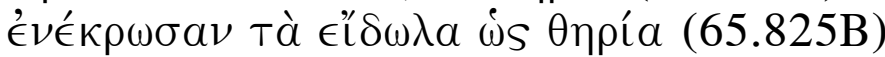

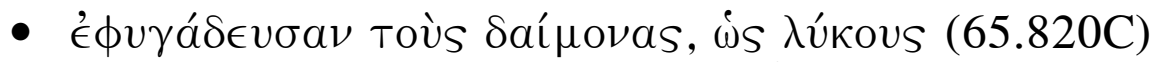

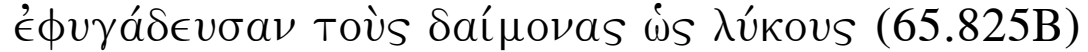

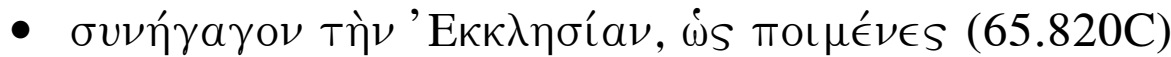

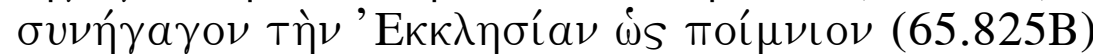

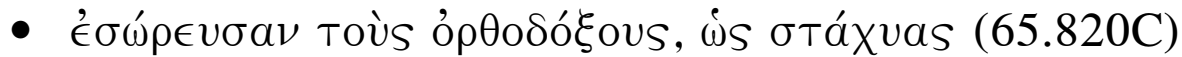

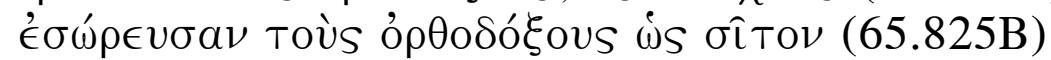

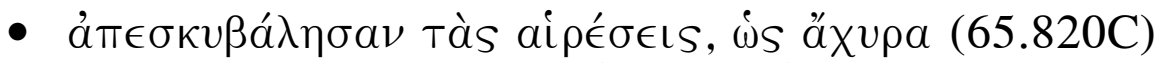

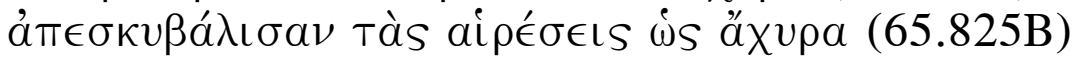

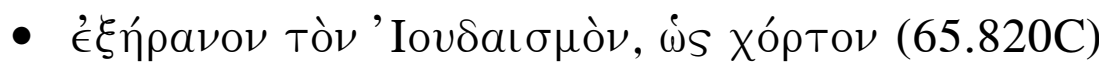

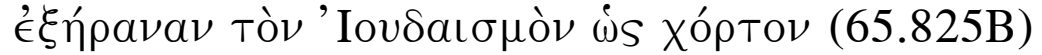

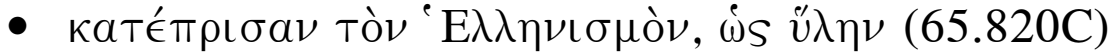

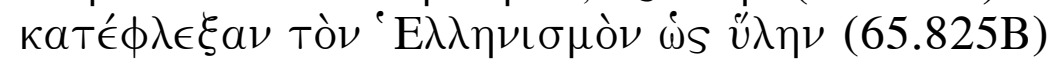

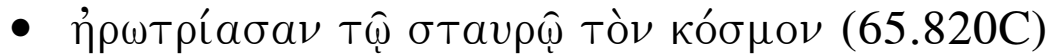

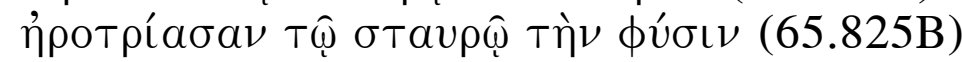

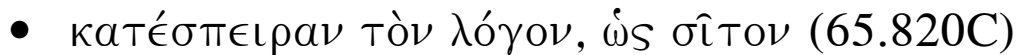

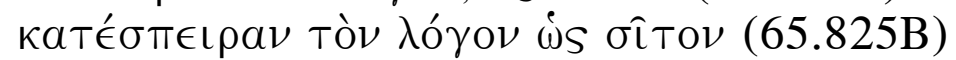

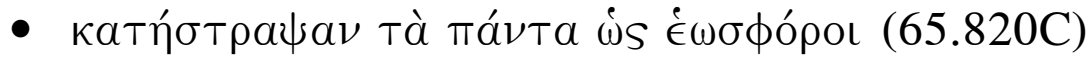

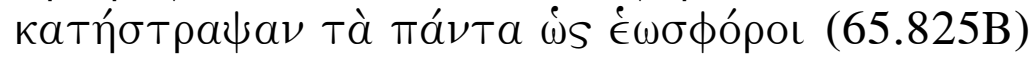




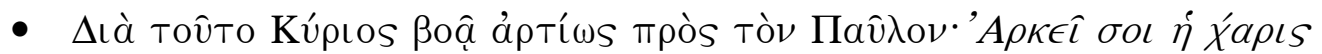

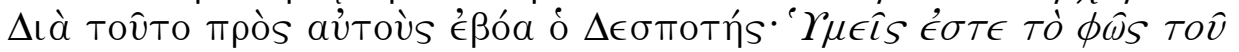

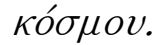

\section{NOTES}

1 Homilies 25 and 30 are in Syriac (and Arabic), homily 6 is not genuine, and homily 20 is spurious. This leaves only homilies $18-19$, translated in this article, to complete my translation of Proclus' homilies.

2 Barkhuizen, Proclus Bishop of Constantinople. Homilies on the Life of Christ, Early Christian Studies 1, Brisbane 2001.

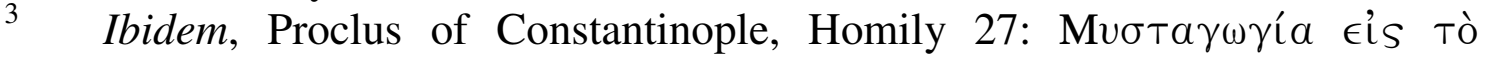

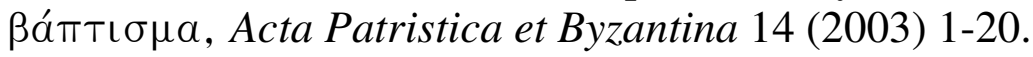

$4 \quad$ Ibidem, 'Proclus of Constantinople, Homily 17: "Encomium on the holy Stephen, First of Martyrs". Translation and Analysis', Acta Patristica et Byzantina 15 (2004) 1-21.

5 Ibidem, Proclus of Constantinople, Encomium on "All the Saints" (Homily 34). Translation and Analysis, Acta Classica 47 (2004) 1-26.

6 See R.A. Lipsius and M. Bonnet, Acta Apostolorum Apocrypha 1, 2 (Leipzig 1891-1903). Andrew was reportedly imprisoned and subsequently martyred in Patras, in Achaia, and Paul in Rome under Nero.

7 While the division of the homily into paragraphs is taken from its edition in $P G$, its division into lines is based on my translation, which tries to follow the rhythmical sentence structure of Proclus' homilies. Cf. Barkhuizen (see note 2) 16-18.

8 The image of the athletic contests is diagnostic as far as the hagiographical genre is concerned. It is significant that Paul frequently employed the agonistic image in his letters.

9 The power invested in relics was a common feature of popular religion, and was adapted by the Christian Church. This concept is already apparent in the NT. It is said, not only, of course, of Jesus himself (cf. inter alia Mt. 9.21), but also of the apostles (Acts 5.15). It is applied to Paul especially in Acts 19.12, to which passage Proclus undoubtedly refers in this instance. See also note 115 .

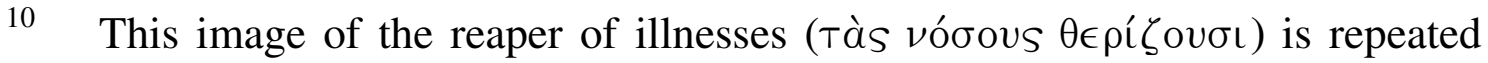
in line 51 ( $\pi \alpha \theta \hat{\omega} \nu \delta \rho \epsilon ́ \pi \alpha \nu \alpha)$.

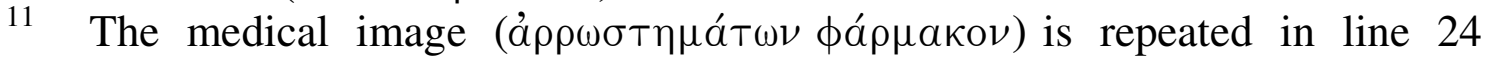

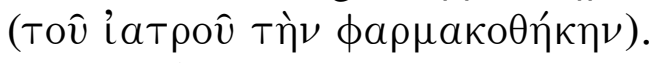

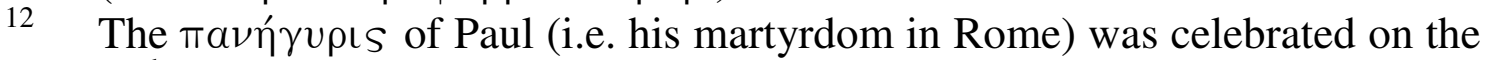
$29^{\text {th }}$ of June (on which day also Peter's martyrdom was celebrated). See J.C.J. Metford, The Christian Year, Thames and Hudson 1991, 111.

13 Boxing (see also line 20) and wrestling (see line 19) were an integral part of the ancient athletic games. 
The idea of 'everything' admiring Paul's contests 'everywhere' is almost a refrain that underlines the eulogiac character of the homily. See also lines $17,42,49,85$ and 89.

This is the culmination of Paul's desire expressed in Phil.1.23: to depart and be with Christ - that is better by far.

Cf. especially 1 Cor.1.19-30, which is almost a hymn on the Wisdom of God, which Paul preached in contrast to the wisdom of man. "A $\beta v \sigma \sigma o s$ in a Christian sense serves as equivalent to Hades, the abode both of the devils and the dead, the place where sinners are punished. See Acts 9.23-25. $\Pi \in \lambda a \gamma i \zeta \omega$ coveys the image of the sea: 'to make something like the sea' i.e. abundant. For a summary of Paul's mission work, see (apart from Acts) Gal.1-2.

Paul was jailed on several occasions - inter alia in Philippi, Jerusalem (Acts 21.27ff), Caesarea (Acts 23.31ff) and Rome, but this line probably refers to the incident in the prison at Philippi (Acts 16.19-40). The military image is likewise part of the language of the hagiographical genre (see note 8 ).

Notice the play upon words: $\pi \tau \hat{\eta} \sigma \iota \nu-\pi \tau \hat{\omega} \sigma \iota \nu$.

For the concept of honour (here of Paul) vs. shame (of the devil) in the encomiastic (hagiographical) genre, see also J.H. Barkhuizen, Proclus of Constantinople, Encomium on "All the Saints" (Homily 34). Translation and Analysis, Acta Classica 47 (2004) 10-11.

See for this inter alia Acts 19.24-40.

For the metaphorical use of $\theta \eta ি \rho a \mu \alpha$, see G.W.H. Lampe, A Patristic Greek Lexicon, Oxford University Press 1982 ed., 651. 
For the medical image see note 11.

An example of inclusio: ai $\mu \nu \hat{\eta} \mu a \iota$ (line 2) $-\dot{\eta} \mu \nu \eta \dot{\mu} \mu \eta$ (line 62).

Eîx€.

Literally: 'put to sleep'. We have here an antithetical metaphor: rising sleeping.

Cf. Luke 1.2: servants of the Gospel.

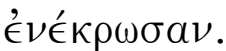

Cf. Matt. $3.12=$ Luke 3.17 .

Ǔ $\eta \nu$.

Or: 'aptly', 'fittingly'.

Cf. Gal. 1.15-16.

Cf. e.g. Acts 21.35-36.

Cf. in general Acts chapters 23-26.

See e.g. Acts 23.12ff.

$\kappa о \sigma \mu \hat{\omega} \sigma \alpha$.

The image contained in $\sigma a \gamma \eta \nu \in \dot{v} \omega$ here and below regarding the Athenians, refers to the 'fishing-net' of the gospel.

Cf. Gal.1.6ff: I am astonished to find you turning away so quickly from him who called you by grace, and following a different gospel; etc.

A double use of the verb $\epsilon^{\prime} \lambda \in \iota \psi \epsilon$, which one could translate in both cases with 'there is a lack of': temptation lacked the devil, but a crown (of victory) was not lacking Paul.

For the medical image see also lines 4 and 24, and also note 11 .

See notes 53 and 68.

See note 11 .

The doxologies at the end of many homilies, where no verb is present, can be translated either as statement (to whom belongs the glory) or wish (to whom be the glory). Here, and in my book on Proclus (note 2), I have interpreted the verb as indicative and not jussive.

Apart from the general eulogiac character of the homily, words such as 'joy' (line 6), 'glory' (line 62), 'amazed' (line 108), 'admire' (line 136), etc. serve to confirm the nature of the homily as eulogy.

Most of the facts surrounding Paul's life are taken from The Acts of the Apostles.

Apart from the main image taken from the world of the $a \gamma \omega \dot{\omega} \nu$, the homily contains a host of other images.

63 For this term see J.Leemans, W.Mayer, P.Allen and B.Dehandschutter, Let us die that we may live. Greek Homilies on Christian Martyrs from Asia Minor, Palestine and Syria (c.AD 350-AD 450), Routledge: London and New York 2003, 22. 
See especially F.J. Leroy, L'homilétique de Proclus de Constantinople, Studi e Testi 247, Vatican City 1967, 166-168; and J.H. Barkhuizen (see note 2) 19-22.

See Leemans, 28 (note 63), said of Hesychius of Jerusalem, but of course, equally and especially true of Proclus - see following note. clus of Constantinople', Acta Patristica et Byzantina 9 (1998) 1-22.

Whereas in homily 18 the dominating image is of Paul the athlete or soldier, in homily 19 it is the image of the fishing net, based on Matt. 4.19: Come with me, and I will make you fishers of men.

The preacher begins his catalogue of splendid and paradoxical things with the murder of Abel by his brother Cain - Gen. 4.1-16. Quotations follow The Revised English Bible.

Noah and the flood - Gen. 6-9.

Abraham and Isaac - Gen. 22.

Abraham entertaining God in his tent - Gen.18.

Jacob - Gen. 27.27-29.

Jacob - Gen. 32.22-32.

The history of Joseph and his brothers - Gen. 37 and following chapters.

Moses and the bramble-bush - Ex. 3.1ff.

Moses before the Pharaoh - Ex. 9.1ff.

The sea turned into dry land - Ex.14.1ff.

At this point there is a gap in the text.

The birth of Samuel - 1 Sam.1.19-20.

Elijah carried up to heaven - II Kings 2.11.

A dead man thrown into the grave of Elisha and then revived by the bones of Elisha - II Kings 13.21.

Notice the technique of inclusio: the idea expressed in line 34 (at the beginning of par.II) is repeated in line 60 (at the end of the paragraph).

See e.g. Mal. 4.2 and Luke 1.78b-79.

Cf. inter alia Matt. 4.18ff.

The Gospel of Luke has specifically developed the concept of the table fellowship - see D.E. Smith, Table Fellowship as a Literary Motif in the Gospel of Luke, Journal of Biblical Studies 106/4 (1987) 613-638.

Cf. John 1.1-3; Col.1.16.

See e.g. Acts 19.11-12: God worked extraordinary miracles through Paul: when handkerchiefs and scarves which had been in contact with his skin were carried to the sick, they were cured of their diseases, and the evil spirits came out of them.

88 For the image of corn and chaff, see Matt. 3.12= Luke 3.17.

89 Peter and Andrew came from Bethsaida - John 1.43-44. 
In homily 11.2 Proclus also has a list of Old Testament figures that were subjected to death in contrast to Christ, whom Death could not conquer. See Barkhuizen (note 2), pp. 159-160.

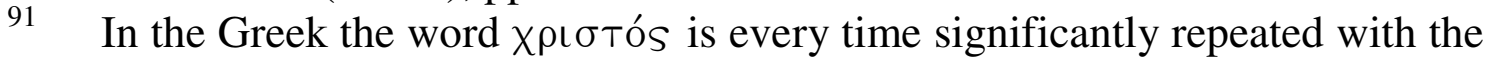
name of an Old Testament figure.

92 Notice the use of inclusio: lines 144/5 are repeated at the conclusion of this section in lines 151/2.

93 See e.g. Acts 3.1-10; 19.11-12. 